\title{
PSIKOLOGI KOMUNIKASI DALAM MENINGKATKAN DAKWAH DA'I DI MASJID FAJAR IKHLAS KELURAHAN SUMBEREJO KECAMATAN KEMILING
}

\author{
Yunidar Cut Mutia Yanti \\ Universitas Islam Negeri Raden Intan Lampung \\ yunidarcutmutia@radenintan.ac.id
}

\begin{abstract}
Communication psychology explains about how to communicate well by taking a psychiatric approach to his mad'u. Because by mastering the psychology of communication, a preacher can adjust the material and the way the delivery of preaching to his madam. So that an effective da'wah can occur. For this, a preacher must use the science of communication psychology in order to be able to understand the state or psychology of his mad'u. Because basically a person's psyche is different, therefore it takes a way to communicate or convey messages in different ways. So an effective da'wah will occur. The research method used is field research (research that is conducted directly in the field or the respondent. The population and sample in this study are the preachers and members of the Ik.hlas Fajar Council. From the results of this study it can be seen that the Da'i at the Fajar Ikblas Mosque, the Da'i have not fully used the science of Communication Psychology, therefore the preaching it delivered was less effective.
\end{abstract}

\section{Abstrak}

Psikologi komunikasi menjelaskan tentang bagaimana cara berkomunikasi yang baik dengan melakukan pendekatan kejiwaan terhadap mad'u nya. Karena 
dengan menguasai psikologi komunikasi, seorang da’i dapat menyesuaikan materi dan cara penyampaian dakwah terhadap mad'u nya. Sehingga dapat terjadi dakwah yang efektif. Atas hal tersebut seorang da'i harus menggunakan ilmu psikologi komunikasi yang baik agar mampu memahami keadaan atau kejiwaan dari mad'u nya. Karena pada dasarnya kejiwaan seseorang berbeda-beda, oleh karena itu diperlukan cara berkomunikasi atau menyampaikan pesan dengan cara-cara yang berbeda pula. Sehingga akan terjadi dakwah yang efektif. Metode penelitian yang digunakan adalah penelitian lapangan (field research) yaitu penelitian yang langsung dilakukan dilapangan atau pada responden. Populasi dan sampel pada penelitian ini adalah para da'i dan anggota Majelis Fajar Ikhlas. Dari hasil penelitian ini dapat diketahui bahwa Da'i di Masjid Fajar Ikblas para Da'i belum sepenubnya menggunakan ilmu Psikologi Komunikasi, oleh kearena itu dakwah yang disampaikannya kurang efektif.

Keywords: Psychology, Communication, Da'i, Da'wah.

\section{A. Pendahuluan}

Dakwah adalah kegiatan mengkomunikasaikan pesan atau ajaran Islam kepada manusia. Dakwah biasanya dilakukan oleh seorang juru dakwah yang biasa disebut da'i. Dakwah bertujuan untuk mempengaruhi dan mengajak manusia mengerjakan kebaikan dan kebenaran yang dijarkan oleh Allah dan Nabi-Nya dalam AlQur'an dan Hadis. Manusia merupakan makhluk berjiwa yang berpikir dan merasa, yang bisa menerima dan menolak sesuai dengan persepsinya terhadap dakwah yang diterimanya. Sudah menjadi keharusan bagi seorang da'i sebelum melakukan dakwahnya ia harus melakukan penelitian sederhana, siapa mad'u yang akan menerima dakwah darinya dan bagaimana kriterianya.

Seorang da'i harus bisa menggunakan ilmu psikologi dalam melaksanakan dakwahnya. Karena dakwah merupakan kegiatan komunikasi, seorang da'i harus mempelajari psikologi komunikasi. Saat ini seorang da'i harus bisa menguasai psikologi komunikasi, agar pesan dakwah yang disampaikan oleh da'i dapat diterima dan dicerna dengan baik oleh mad'u.

Psikologi adalah ilmu yang berusaha menguraikan meramalkan dan mengendalikan peristiwa mental dan tingkah laku 
manusia. Dengan komunikasi kita membentuk saling pengertian menumbuhkan persahabatn, memlihara kasih sayang, menyebarkan pengetahuan, dan melestarikan peradaban. Psikologi komunikasi menjelaskan tentang bagaimana cara berkomunikasi yang baik dengan melakukan pendekatan kejiwaan terhadap mad'u nya. Karena dengan menguasai psikologi komunikasi, seorang da'i dapat menyesuaikan materi dan cara penyampaian dakwah terhadap mad'u nya. Sehingga dapat terjadi dakwah yang efektif.

Di Indonesia saat ini, sudah banyak terbentuk pengajian yang di dalamnya beranggotakan ibu-ibu rumah tangga, pengajian tersebut di isi dengan berbagai kegiatan yang membahas tentang kajian keIslaman, dan kegiatan sosial. Pengajian ini biasanya disampaikan dengan mengandung nilai-nilai moral, etika, sopan santun, dan budi pekerti yang sesuai dengan ajaran Agama Islam. Banyak dari ibu-ibu pengajian yang sengaja mengikuti kegiatan seperti ini dengan tujuan menambah pengetahuannya tentang ajaran agama Islam itu sendiri.

Dengan berkembangnya pengaiian atau majelis ta'lim pada saat ini, hal itu harus dibarengi dengan kualitas dari seorang da'i dalam menyampaikan dakwahnya. Apakah ketika seorang da'i meyampaikan dakwahnya mudah dipahami dan dicerna oleh mad'u ataukah sebaliknya. Atas hal tersebut seorang da'i harus menggunakan ilmu psikologi komunikasi yang baik agar mampu memahami keadaan atau kejiwaan dari mad'u nya. Karena pada dasarnya kejiwaan seseorang berbeda-beda, oleh karena itu diperlukan cara berkomunikasi atau menyampaikan pesan dengan cara-cara yang berbeda pula. Sehingga akan terjadi dakwah yang efektif.

Dakwah yang efektif terjadi apabila mad'u dapat mendengarkan, menerima, mencerna dan menerapkan pesan dakwah yang disampaikan dalam dakwah tersebut. Oleh karena itu peniliti menilai perlu melakukan penelitian terhadap da'i yang dalam penyampaian dakwahnya menerapkan psikologi komunikasi yang khususnya digunakan oleh da'i di Masjid Fajar Ikhlas. Hal tersebut 
untuk mengetahui bagaiamana peran psikologi komunikasi dalam meningkatkan dakwah da'i. ${ }^{1}$

\section{B. Kerangka Teori}

1. PengertianPsikologi Komunikasi

Psikologi menurut bahasa berasal dari kata Yunani yang terdiri dari dua kata, psyche dan logos. Psyche berarti jiwa dan logos berarti ilmu. Jadi, psikologi secara bahasa dapat berarti 'ilmu jiwa'. Menurut Sarlito, tidak ada seorangpun yang tahu dengan sesungguhnya apa yang dimaksud dengan jiwa itu sendiri, karena jiwa adalah suatu kekuatan yang abstrak yang tidak tampak oleh pancaindra wujud dan zatnya, melainkan yang tampak hanya gejala-gejalanya saja ${ }^{2}$.

Komunikasi menurut Rogers dan D. Lawrence Kincaid (1981) adalah suatu proses dimana dua orang atau lebih membentuk atau melakukan pertukaran informasi dengan satu sama lainnya, yang pada gilirannya akan tiba saling pengertian yang mendalam ${ }^{3}$. Definisi komunikasi juga disampaikan oleh Harrold D Laswell yaitu dengan menjawab pertanyaan Who Says What In Which Channel To Whom With What Effect. Jadi berdasarkan paradigma Lasswell tersebut, komunikasi adalah proses penyampaian pesan oleh komunikator kepada komunikan melalui media yang dapat menimbulkan efek tertentu. ${ }^{4}$

Menurut Miller 1974, Psikologi komunikasi diartikan sebagai "Psychology is the science that attemps to describe, predict, and control mental and behavioral events" (ilmu yang berusaha menguraikan, meramalkan dan

${ }^{1}$ Kiki Muhamad Hakiki dan Zaenal Muttaqien, Konflik dan Integrasi Sosial (Telaah Buku A. Malik. MTT berjudul "Pura dan Masjid; Konflik dan Integrasi Pada Suku Tengger Jawa Timur), Al-AdYaN/Vol. IX, N0. 2/Juli-Desember/2014, h. 44

${ }^{2}$ Lalu Muchsin Effendi dan Faizah, Psikologi Dakwah, Jakarta: Kencana, 2006), h.1-2.

${ }^{3}$ Hafied Cangara, Pengantar Ilmu Komunikasi, Jakarta: PT. Raja Grafindo Persada, 2012), h.22.

${ }^{4}$ OnongUchjanaEfendi, IlmuKomunikasiTeoridanPraktek, (Bandung : PT. RemajaRosdakarya, 2009), h.10. 
mengendalikan peristiwa mental dan behavioral (perilaku) dalam komunikasi). ${ }^{5}$

Menguraikan berarti suatu kegiatan menganalisis, mengapa suatu tindakan komunikasi bisa terjadi, apa yang terjadi dalam diri kita sehingga tindakan tersebut bisa terjadi. Meramalkan berarti membuat suatu generalisasi tertentu atas sejumlah perilaku tertentu yang dihubungkan dengan kondisi psikologis tertentu, maka kita akan bisa meramalkan bentuk perilaku apa yang akan muncul jika suatu stimulus diberikan kepada orang dengan karatek psikologis tertentu. Dan mengendalikan berarti kita bisa melakukan campur tangan tertentu (manipulasi) jika kita menginginkan atau tidak menginginkan suatu efek tertentu dari suatu komunikasi yang dilakukan.

Bila individu-individu berinteraksi dan saling mempengaruhi, maka terjadilah (1) proses belajar yang meliputi aspek kognitif dan afektif (aspek berpikir dan merasa), (2) proses penyampaian dan penerimaan lambang-lambang (Komunikasi), dan (3) mekanisme penyesuaian diri seperti sosialisasi, permainan peranan, identifikasi, proyeksi, agresi dan sebagainya. ${ }^{6}$

\section{Ruang Lingkup Psikologi Komunikasi}

Psikologi menyebut komunikasi pada penyampaian energi dari alat-alat indera ke otak, pada peristiwa penerimaan dan pengolahan informasi, pada proses saling pengaruh diantara berbagai sistem dalam diri organisme dan diantara organisme. ${ }^{7}$

Psikologi mencoba menganalisa seluruh komponen yang terlibat dalam proses komunikasi. Pada diri komunikan psikologi memberikan karakteristik manusia komunikan serta faktor-faktor internal maupun eksternal yang mempengaruhi perilaku komunikasinya. Pada saat pesan sampai pada diri komunikator, psikologi melihat kedalam proses penerimaan pesan, menganalisa faktor-faktor personal dan situasional yang mempengaruhinya, dan

5Jalaludin Rakhmat, Psikologi Komunikasi, (Bandung: PT. Remaja Rosdakarya, 2007), h. 9.

${ }^{6}$ Ibid, h.10.

${ }^{7}$ Ibid, h. 4. 
menjelaskan berbagai corak komunikan ketika sendirian atau dalam kelompok. ${ }^{8}$

3. Ciri Pendekatan Psikologi Komunikasi

Menurut Fisher terdapat empat ciri pendekatan psikologi pada komunikasi yaitu:

a. Penerimaan stimuli secara indrawi (sensory reception of stimuli)

b. Proses yang mengantari stimuli dan respon (internal mediation of stimuli)

c. Prediksi respons (prediction of response)

d. Peneguhan respons (reinforcement of responses)

Psikologi melihat komunikasi dimulai dengan dikenainya masukan kepada organ-organ pengindraan kita yang berupa data. Stimuli berbentuk orang, pesan, suara, warna yaitu segala hal yang mempengaruhi kita. Stimuli ini kemudian diolah dalam jiwa kita dalam "kotak hitam" yang tidak pernah kita ketahui. Kita hanya bisa mengambil kesimpulan tentang proses yang terjadi pada kotak hitam dari respon yang tampak, seperti tersenyum, tepuk tangan, meloncat itu adalah bahagia. ${ }^{9}$

4. Psikologi Komunikator

Aristoteles menulis persuasi tercapai karena karakteristik personal pembicara yang ketika ia menyampaikan pembicaraannya kita menganggapnya dapat dipercaya. (Aristoteles, 1954:45)

Aristoteles menyebut karakter komunikator ini sebagai ethos. Ethos terdiri dari pikiran baik, akhlak yang baik, dan maksud yang baik (good sense, good moral character, good wiil). ${ }^{10}$

Ethos atau faktor-faktor yang mempengaruhi efektivitas komunikator terdiri dari kredibilitas, atraksi, dan kekuasaan. Ketiga dimensi ini berhubungan dengan jenis pengaruh sosial yang ditimbulkannya. ${ }^{11}$

${ }^{8}$ Ibid, h. 5.

${ }^{9}$ Ibid, h.8-9.

${ }^{10}$ Ibid, h. 255.

${ }^{11} \mathrm{Ibid}$, h. 256 
Kredibilitas adalah seperangkat persepsi komunikate tentang sifat-sifat komunikator. Dalam definisi ini terkandung dua hal yaitu (1) kredibilitas adalah pesepsi komunikate jadi tidak inheren dalam diri komunikator (2) kredibilitas berkenaan dengan sifat-sifat komunikator, yaitu selanjutnya akan kita sebut komponen-komponen kredibilitas. $^{12}$

Faktor-faktor situasional yang mempengaruhi atraksi interpersonal yaitu fisik, ganjaran, kesamaan, dan kemampuan. ${ }^{13}$ Oleh karena itu ketika sorang komunikator memiliki sebuah kesamaan terhadap komunikannya, maka akan timbulah komunikasi yang efektif.

Selain kredibilitas dan atraksi, terdapat satu dimensi lain dari ethos yaitu kekuasaan. Kekuasaan adalah kemampuan menimbulkan ketundukan. Ketundukan timbul dari interaksi antara komunikator dan komunikate. ${ }^{14}$

Dari penjelasan tersebut maka seorang Da’i harus menjadi psikologi komunikator, agar dapat menyampaikan pesan dakwahnya secara efektif kepada mad'unya.

\section{Pengertian Dakwah}

Dakwah memiliki makna atau pengertian berdasarkan etimologi dan terminology. Dakwah secara etimologi merupakan bentuk masdar dari kata yad'u (fi'il mudhari') dan da'a (fi'il madii) yang berarti memanggil (to call), mengundang (to invite), mengajak (to summer), menyeru (to propo), mendorong (to urge), dan memohon (to pray). Sedangkan pengertian dakwah secara terminology yaitu menurut syekh Ali Mahfud adalah dakwah merupakan kegiatan mendorong atau memotivasi manusia untuk melakukan kebajikan dan mengikuti petunjuk, memerintahkan mereka untuk berbuat ma'ruf dan mencegah kepada yang mungkar agar mereka mendapat kebahagiaan dunia dan akhirat. ${ }^{15}$

${ }^{12}$ Ibid, h. 257.

${ }^{13}$ Ibid, h.261.

${ }^{14}$ Ibid, h. 265.

${ }^{15}$ Farizamakmun, Dakwah Pembangunan, (Lampung:Pusikamla, 2009), h.12-

14. 


\section{Da'i dan Kepribadiannya}

\section{Pengertian Da'i}

Kata Da'i berasal dari bahasa arab bentuk mudzakar yang berarti orang yang mengajak. Sedangkan jika muanats disebut Daiyah. Jadi yang dimaksud dengan Da'i adalah orang yang mengajak orang lain, baik secara langsung maupun tidak langsung, melalui lisan, tulisan maupun perbuatan untuk mengamalkan ajaran-ajaran Islam atau menyebarluaskan ajaran Islam, melakukan upaya perubahan kearah kondisi yang lebih baik menurut Islam. ${ }^{16}$

Diantara modal kesuksesan dai ialah

1. Sabar

2. Mengetahui psikologi dakwah

3. Memiliki kemampuan dalam ilmu (khususnya agama)

4. Memiliki akhlak yang baik

5. Memiliki persiapan materi yang cukup

Untuk membuat suatu proses dakwah sesuai dengan yang diharapkan, seorang Da'i harus memiliki kriteria kepribadian yang dipandang positif oleh ajaran Islam dan masyarakat. Sifat-sifat seorang da'i memang sangat banyak dan beragam dan sangat sulit untuk merumuskannya. Namun paling tidak Al-qur'an dan Sunnah Nabi serts tingkah laku para sahabat dan ulama dapat dijadikan sebagai aturan. ${ }^{17}$

\section{Kepribadian Da’i}

Subyek dakwah atau Da'i merupakan unsur terpenting dalam pelaksanaan dakwah, karena manusia sebagai pelaku dakwah adalah unsur yang paling penting dan menentukan.

Suksesnya suatu usaha dakwah tergantung juga kepada kepribadian da'i yang bersangkutan. Apabila da'i mempunyai kepribadian yang menarik insyaallah dakwahnya akan berhasil dengan

\footnotetext{
${ }^{16}$ AwaludinPimay (dalam Hand Out.PengantarIlmuDakwah) h. 9.

${ }^{17}$ Lalu Muchsin Effendi dan Faizah, Psikologi Dakwah, Jakarta: Kencana, 2006), h.90.
} 
baik, dan sebaliknya jika da'i tidak mempunyai kepribadian yang baik atau tidak mempunyai daya tarik, maka usaha itu akan mengalami kegagalan.

Gambaran kepribadian seorang da'i sebagaimana dijelaskan Hamka ada delapan perkara yang perlu diperhatikan, antara lain:

a. Hendaknya seorang da'i memiliki dan menyelidiki benar-benar kepada dirinya sendiri, untuk apa dia mengadakan dakwah (menyangkut masalah niat),

b. Hendaklah seorang pendakwah mengikuti mengerti benar soal yang akan disampaikan.

c. Terutama sekali kepribadian da'i haruslah kuat dan teguh, tidak terpengaruh oleh pandangan orang banyak ketika memuji dan tidak tergoncang ketika mata orang melotot karena tidak senang. Jangan ada cacat pada perangai, meskipun ada cacat pada jasmaninya.

d. Pribadinya menarik, lembut tetapi bukan lemah, tawadlu' merendahkan diri tetapi bukan rendah diri, prmaaf tetapi disegani. Dia duduk di tengah orang banyak, namun dia tetap tinggi dari orang banyak.

e. Harus mengerti pokok pegangan kita ialah A;-Qur'an dan AsSunna. Di samping itu harus mengerti ilmu jiwa (ilmu nafs) dan mengerti pula adat istiadat orang yang hendak di dakwahi.

f. Jangan membawa sikap pertentangan,jauhkan dari sesuatu yang akan membawa debat (tidak perlu membuka masalah khilafiyah di muka orang banyak atau orang awam)

g. Haruslah diinsafi behwasanya contoh teladan dalam sikap hidup, jauh lebih berkesan kepada jiwa umat dari pada ucapan yang keluar dari mulut.

h. Hendaklah da'i itu menjaga jangan sampai ada sifat kekuranga yang akan menguragi gengsinya dihadapan pengikutnya. Karena sangat menghalangi kelancaran gagasan dan anjuran yang dikemukakan.

1) Kepribadian Rohaniah 
Kriteria kepribadian yang baik sangat menentukan keberhasilan dakwah, karena pada hakikatnya berdakwah tidak hanya menyampaikan teori, tapi juga harus memberikan teladan bagi umat yang diseru. Adapun Sifat-sifat seorang Da’i adalah sebagai berikut:

a) Beriman dan Bertakwa Kepada Allah SWT

b) Ahli Tobat

c) Ahli Ibadah

d) Amanah dan Shidq

e) Pandai Bersyukur

f) Tulus Ikhlas dan Tidak Mementingkan Pribadi

g) Ramah dan Penuh Pengertian

h) Tawaddu (Rendah Hati)

i) Sederhana dan Jujur

j) Tidak memiliki Sifat Egois

k) Sabar dan Tawakal

1) Memiliki Jiwa Toleran

m) Sifat Terbuka (Demokratis)

n) Tidak Memiliki Penyakit Hati

Selain itu ada beberapa sikap yang harus dimiliki oleh seorang Da'i yaitu :

a) Berakhlak Mulia

b) Teladan yang Baik bagi Masyarakat

c) Disiplin dan Bijaksana

d) Wara' dan berwibawa

e) Berpandangan luas

f) Berpengetahuan yang cukup

2) Kepribadian yang Bersifat Jasmani

a) Sehat Jasmani

b) Berpakaian sopan dan rapi 
Selain itu Achmad Mubarok dalam psikologi dakwah menambahkan bahwa seorang Da'i harus memiliki beberapa kemampuan diantaranya ${ }^{18}$

1) Kemampuan berkomunikasi

2) Pemberani

3) Materi Dakwah

Secara umum, materi dakwah diklasifikasikan menjadi empat masalah pokok, yaitu :

a. Masalah akidah (keimanan)

Aspek akidah adalah yang akan membentuk moral (akhlak) manusia. Oleh karena itu, masalah yang paling utama yang menjadi dasar bagi seorang manusia.

Ciri-ciri yang membedakan aqidah dengan kepercayaan agama lain yaitu :

- Keterbukaan melalui persaksian (syahadat)

- Cakrawala pandangan yang luas dengan memperkenalkan bahwa Allah adalah Tuhan seluruh alam

- Ketahanan antara iman dan Islam atau antara iman dan amal perbuatan.

Seseorang yang memiliki iman yang kuat tidak akan mudah terpengaruh dengan perbuatan buruk.

b. Masalah Syariah

Masalah syaraiah mencakup kemashalahatan sosial dan moral. Syariah juga menyangkut aktivitas manusia di dalam semua aspek hidup dan kehidupannya, mana yang boleh dilakukan, mana yang tidak boleh dilakukan.

c. Masalah Muamalah

Masalah muamalah merupakan suatu masalah yang harus dijadikan materi dakwah. Karena ibadah dalam muamalah ini diartikan sebagai ibadah yang mencakup hubungan dengan Allah SWT dalam rangka mengabdi kepada Allah SW'T.

${ }^{18}$ Ibid, h.101. 


\section{d. Masalah Akhlaq}

Akhlaq yaitu menyangkut tata cara berhubungan baik secara vertikal dengan Allah SWT, maupun secara horizontal dengan sesama manusia dan seluruh makhluk-makhluk Allah.

\section{E. Metode Penelitian}

Metode merupakan suatu cara yang tepat untuk melakukan sesuatu dalam mencapai tujuan dengan teknik dan alat tertentu. Metode penelitian berarti proses pencarian data meliputi penentuan populasi, sampling, penjelasan konsep dan pengukurannya, cara-cara pengumpulan data dan teknik analisisnya. ${ }^{19}$

\section{PendekatanPenelitian}

Penelitian ini menggunakan pendekatan kualitatif. Secara terminologis penelitian kualitatif menurut Bogdan dan Taylor merupakan prosedur penelitian yang menghasilkan data deskriptif berupa kata-kata terulis atau lisan dari orang-orang dan pelaku yang diamati. ${ }^{20}$ Metodologi kualitatif lebih suka mrnggunakan teknik analisis mendalam (in-depth analysis), yaitu mengkaji masalah secara kasus per kasus karena metodologi kualitatif yakin bahwa sifat masalah yang satu berbeda dengan sifat masalah lainnya. Temuan yang dihasilkan dari metodologi kualitatif bukam generalisasi, tetapi pemahaman secara mendalam terhadap suatu masalah atau fenomena. ${ }^{21}$

2. JenisdanSifatPenelitian

\section{a. Jenis Penelitian}

Sesuai dengan permasalahan yang akan diteliti, dapat dipastikan bahwa adalah penelitian lapangan (field research) yaitu penelitian yang langsung dilakukan dilapangan atau pada responden. ${ }^{22}$

${ }^{19}$ Cholid Naburko dan Abu Achmadi, Metodologi Penelitian, (Jakarta: Bumi Aksara, 2010), h.1.

${ }^{20}$ Lexy J. Moeleong, Metode Penelitian Kualitatif, (Bandung: PT. Remaja Rosdakarya, 2013), h.4.

${ }^{21}$ Sumanto, Teori dan Aplikasi Metode Penelitian, (Jakarta: CAPS (Center of Academic Publishing Service), 2014), h.9-10

${ }^{22}$ M. Hasan Iqbal, Pokok-Pokok Materi Metodologi Penelitian dan Aplikasinya, (Jakarta: Ghia Indonesia, 2002), h.11 
Penelitian ini merupakan jenis penelitian lapangan karena peneliti bertemu langsung dengan para Da'i dan jamaah Majelis Taklim Fajar Ikhlas.

b. Sifat Penelitian

Dalam penelitian ini peneliti menggunakan jenis penelitian deskriptif. Penelitian deskriptif berusaha mendeskripsi dan menginterpretasi apa yang ada (bisa mengenai kondisi atau hubungan yang ada, pendapat yang sedang tumbuh, proses yang sedang berlangsung, akibat atau efek yang terjadi atau kecenderungan yang tengah berkembang). ${ }^{23}$

\section{Sumber Data}

Data yang dipergunakan penulis dalam penelitian ini ada dua macam sumber data, yaitu data primer dan data sekunder.

a. Data Primer

Data primer adalah data yang secara langsung diperoleh dari masyarakat baik yang dilakukan melalui wawancara, observasi dan alat lainnya. ${ }^{24}$ Dalam hal ini data yang utama adalah para Da’i dan Mad'u di Masjid Fajar Ikhlas.

b. Data Sekunder

Data sekunder adalah data yang diperoleh dari atau berasal dari bahan kepustakaan. ${ }^{25}$ Data sekunde juga merupakan data pelengkap. Dalam hal ini penulis menggambil data melalui buku, artikel, jurnal internet, dan dokumen-dokumen yang ada.

4. Populasi dan Sampel

a. Populasi

Populasi adalah kelompok di mana seseorang peneliti akan memperoleh hasil penelitian yang dapat disamaratakan

${ }^{23}$ Sumanto, Teori dan Aplikasi Metode Penelitian, (Jakarta: CAPS (Center of Academic Publishing Service), 2014), h.179

${ }^{24}$ P. Joko Subagyo, Metode Penelitian Dalam Teori Dan Praktik, (Jakarta: Rineka Cipta, 2015), h.87

${ }^{25}$ Ibid, h.88 
(digeneralisasikan). ${ }^{26}$ Pada penelitian ini populasinya adalah seluruh anggota pengajian dan para Da'i dari Masjid Fajar Ikhlas.

b. Sampel

Sampling adalah proses pemilihan sejumlah individu (objek penelitian) untuk suatu penelitian sedemikian rupa sehingga individu-individu (objek penelitian) tersebut merupakan perwakilan kelompok yang lebih besar pada mana objek itu dipilih $^{27}$. Sampel yang digunakan penulis dalam penelitian ini adalah para Da'i dari pengajian Masjid Fajar Ikhlas.

\section{Metode Pengumpulan Data}

a. Observasi

Observasi adalah pengamatan yang dilakukan secara sengaja, sistematis mengenai fenomena sosial dengan gejala-gejala psikis untuk kemudian dilakukan pencatatan ${ }^{28}$.

b. Wawancara

Metote pengumpulan data melalui wawancara yaitu suatu kegiatan dilakukan untuk mendapatkan informasi secara langsung dengan mengungkapkan pertanyaan-pertanyaan pada para responden ${ }^{29}$.

c. Dokumentasi

Metode dokumentasi adalah mencari data mengenai hal-hal atau variabel yang serupa catatan, buku, surat, majalah dan sebagainya. Metode dokumentasi ini digunakan setelah melakukan metode wawancara dan observasi. Tujuannya adalah untuk melengkapi data. ${ }^{30}$

d. Analisis Data

${ }^{26}$ Sumanto, Teori dan Aplikasi Metode Penelitian, (Jakarta: CAPS (Center of Academic Publishing Service), 2014), h.160

${ }^{27}$ Ibid, h.160

${ }^{28}$ P. Joko Subagyo, Metode Penelitian Dalam Teori Dan Praktik, (Jakarta: Rineka Cipta, 2015), h.63

${ }^{29}$ Ibid, h.39

${ }^{30}$ Cholid Naburko dan Abu Achmadi, Metodologi Penelitian, Jakarta: Bumi Aksara, 2010), h. 98. 
Analisis data adalah proses mengorganisasikan dan mengurutkan data ke dalam pola, kategori, dan satuan uraian dasar sehingga dapat ditemukan tema, dan dirumuskan tema dan hipotesa kerja seperti yang disarankan oleh data. Prinsip utama dalam analisa data adalah bagaimana menjadikan data atau informasi yang telah dikumpulkan disajikaan dalam bentuk uraian dan sekaligus memberikan makna atau interpretasi sehingga informasi tersebut memiliki signifikan ilmiah atau teoritis. ${ }^{31}$

\section{F. Pembahasan}

\section{Dakwah Efektif}

Sebagai solusi untuk memudahkan seorang dai menyampaikan pesan. Sebenarnya banyak cara untuk berkomunikasi dengan baik, di antaranya adalah hal berikut ini:

a. Komunikasi yang ampuh adalah datang dari kekuatan dalam. Jangan mencoba menguasai orang lain secara paksa.

b. Bergaullah dengan setiap orang dalam pekerjaan, perkemahan atau kelompok Anda, dan kurangnya waktu bukanlah alasan yang tepat.

c. Gunakan waktu istirahat anda untuk bertemu dengan orang yang berbeda. Rencanakan untuk makan bersama dengan orang lain. Anda akan membina hubungan yang sangat berarti dengan setiap orang dengan waktu yang singkat.

d. Jangan menunggu yang datang lambat dalam suatu pertemuan. Jika anda lakukan itu, sama halnya anda mengajarkan pada mereka bahwa terlambat adalah boleh-boleh saja, demikian juga menghukum orang yang lebih awal

e. Uraikan dengan kata-kata sendiri pesan yang anda dengar untuk memastikan penyampaian dan penerimaan yang tepat.

f. Ingatlah, semakin banyak yang kita pahami, semakin banyak yang dapat kita atur dan semakin kurang kita memahami semakin banyak kita memanipulasi.

${ }^{31}$ Ibid, h. 280. 
Dakwah yang disampaikan oleh da'i di masjid Fajar Ikhlas sudah sedikit memasuki kategori dakwah yang efektif. Komunikasi efisien berhubungan dengan pemanfaatan atau optimalisasi waktu dan biaya dalam pertukaran informasi. Komunikasi dapat dikatakan efisien jika pesan yang disampaikan oleh komunikator kepada audience, melalui suatu saluran lebih murah dibandingkan melalui saluran lain, tanpa mengurangi esensi atau inti dari informasi tersebut. Sedangkan komunikasi efektif merupakan komunikasi yang mengandung pengiriman informasi dari komunikator kepada komunikan secara cermat dan tepat, sehingga kedua pihak memahami makna yang terkandung dalam informasi tersebut. Komunikasi efektif tergantung pada penggunaan bahasa yang sesuai, kejelasan makna, dan media yang digunakan.

Bertitik tolak dari firman Allah dalam Q.S An-Nahl ayat 125 bahwa ada tiga metode dalam berdakwah yaitu bikmah, manidzahbasanah, dan mujadalah. Ketiga metode tersebut menunjukkan urgensi komunikasi begitu signifikan dalam dunia dakwah. Hal ini dikarenakan salah satu cara yang banyak digunakan dalam usaha dakwah ialah melalui komunikasi efektif, sehingga pokok atau tujuan dakwah sesuai dengan apa yang diharapkan. Dalam konteks dakwah, tentunya diperlukan kecakapan khusus bagi seorang penceramah atau da'i agar bisa berkomunikasi secara efektif. Komunikasi efektif sangat terkait dengan optimalisasi waktu dalam memberikan pesan, sehingga informasi yang disampaikan ataupun yang diterima tepat sesuai sasaran dan memberikan pemahaman makna yang mendalam. Komunikasi dakwah menjadi efektif jika materi dakwah disampaikan oleh penceramah atau da'i, sedemikian rupa sehingga dapat dimengerti sepenuhnya oleh audience atau mustami. Dalam komunikasi tersebut harus ada suatu ketetapan pikiran oleh kedua belah pihak apalagi komunikasi efektiftersebut berhubungan dengan dunia dakwah.

Dari hasil wawancara yang dilakukan peneliti terhadap salah satu da'i di masjid Fajar Ikhlas, bahwasanya dalam menyampaikan dakwahnya seorang da'i melihat terlebih dahulu bagaimana kondisi mad'unya. Apakah mereka benar-benar memperhatikan ceramah yang disampaikan atau hanya terdiam tanpa memberikan respon. Jika audiens terdiam tanpa memberikan respon, sang da;i harus segera menemukan cara komunikasi yang dapat menarik perhatian dari 
audiens. Misalkan dengan menggunakan kisah-kisah pada zaman dahulu. Atau menceritakan pengalaman dari seseorang sesuai dengan tema dari ceramahnya. Komunikasi dakwah efektif sesungguhnya ditegaskan dalamAlquran sebagimana firman Allah dalam (Q.S.16 $: 125)$ :

Artinya: "Serulah (manusia) kepada jalan Tuban-mu dengan bikmah dan pelajaran yang baik dan bantablah mereka dengan cara yang baik. Sesunggubnya Tuhanmu Dialah yang lebih mengetahui tentang siapa yang tersesat dari jalan-Nya dan Dialah yang lebih mengetahui orangorang yang mendapat petunjuk."

Berdasarkan hasil yang disesuaikan dengan teori yang ada bahwasanya terdapat perbedaan antara para da'i dalam menyampaikan dakwahnya. Mereka memiliki cara tersendiri terhadap penyampaian dakwahnya sehingga dakwah yang disampaikan dapat dipahami dan dimengerti oleh para jamaah. Perbedaan cara penerapan psikologi komunikasi ini adalah akibat latar belakang pendidikan yang berbeda. Selain itu juga faktor budaya dan faktor psikologi serta kredibilatas seorang da'i. Seperti yang telah dijelaskan bahwa ada beberapa hal yang menjadi modal kesuksesan dakwah da'i salah satunya adalah memahami psikologi dakwah dan komunikasi serta memiliki kemampuan yang baik dalam bidang Keislaman

\section{G. Penutup}

Berdasarkan hasil penelitian dan pembahasan dapat kita diambil kesimpulan bahwa seseorang yang melakukan dakwah haruslah mempelajari psikologi komunikasi dan psikologi dakwah. Karena dengan mempelajari dan menerapkan psikologi sebelum melaksanakan dakwahnya, akan lebih mudah dipahami dan dimengerti oleh mad'unya. Dengan adanya psikologi komunikasi yang ditunjang dengan kepribadian da'i yang baik, dakwah yang disampaikannya akan menjadi dakwah yang efektif, sehingga menimbulkan dampak bagi para jamaahnya.Dari hasil analisa data penelitian ini dapat disimpulkan bahwa da'i di masjid Fajar Ikhlas harus bisa menjiwai dan dapat memberi kan materi sesuai dengan mad'u yang ada di masjid tersebut. 
Dan berdasarkan analisa di teori dan di lapangan bahwa da'i harus bisa menjiwai keadaan psikologis dan pendidikan mad'u nya selain itu juga seorang da'i harus dapat menyesuaikan materi dakwah yang disampaikan. Sehingga dakwah yang disampaikan dapat di mengerti serta dipahami oleh mad'u nya. Dan untuk mad'u nya agar lebih aktif dalam mengikuti pengajian yang dilakukan di masjid Fajar Ikhlas. Setelah memahami dapat di aplikasikan kedalam kehidupan sehari-hari.

\section{Daftar Pustaka}

Awaludin Pimay, dalam Hand Out.Pengantar Ilmu Dakwah.

Cholid Naburko dan Abu Achmadi, Metodologi Penelitian, Jakarta: Bumi Aksara, 2010.

Fariza Makmun, Dakwah Pembangunan, Lampung:Pusikamla, 2009.

Hafied Cangara, Pengantar Ilmu Komunikasi, Jakarta: PT. Raja Grafindo Persada, 2012.

Jalaludin Rakhmat, Psikologi Komunikasi, Bandung: PT. Remaja Rosdakarya, 2007.

Kiki Muhamad Hakiki dan Zaenal Muttaqien, Konflik dan Integrasi Sosial (Telaah Buku A. Malik MTT berjudul "Pura dan Masjid; Konflik dan Integrasi Pada Suku Tengger Jawa Timur), AlAdYaN/Vol. IX, N0. 2/Juli-Desember/2014

Lalu Muchsin Effendi dan Faizah, Psikologi Dakwah, Jakarta: Kencana, 2006.

Lexy J. Moeleong, Metode Penelitian Kualitatif, Bandung: PT. Remaja Rosdakarya, 2013.

M. Hasan Iqbal, Pokok-Pokok Materi Metodologi Penelitian dan Aplikasinya, Jakarta: Ghalia Indonesia, 2002. 
Onong Uchjana Efendi, Ilmu Komunikasi Teori dan Praktek, Bandung : PT. Remaja Rosdakarya, 2009.

P. Joko Subagyo, Metode Penelitian Dalam Teori Dan Praktik, Jakarta: Rineka Cipta, 2015.

Sumanto, Teori dan Aplikasi Metode Penelitian, Jakarta: CAPS (Center of Academic Publishing Service), 2014. 